\title{
Project the day focused on physical activity and diet ${ }^{1}$
}

\author{
Jitka Tomanová ${ }^{2}$ \\ Petr Zemánek ${ }^{3}$
}

\begin{abstract}
Healthy physical activity and well-balanced diet are means of maintaining and promoting health. The presented Project Day involving pupils of the $1^{\text {st }}$ level of elementary school in Senice na Hané focuses on well-balanced diet and health enhancing physical activity in terms of the current educational reality. These two phenomena are inseparable. One is associated with the other, they complement each other. They are the two crucial aspects of a healthy lifestyle of each individual. Without a balanced and appropriate diet, physical activity of pupils is useless. The main objective of the Project Day called "A sound mind in a sound body" was to, in a playful way, familiarize the pupils with basic information concerning diet and health benefits of physical activity. The aim of the initial part was to motivate the pupils for activity at various activity points. This part included a brief introduction with information about division into groups, duration at various activity points (length of activity at a specific activity point and length of transfers between activity points). The pupils were shown a short sketch, which symbolised a "clash" between the importance of diet and physical activity for humans. In their groups, the pupils were supposed to answer the principal motivation question: What is healthier for a human? Healthy food or sport? The following main part of the Project Day held on 2 December 2014 was attended by 69 pupils and was organized as group work at various thematic activity points. Each group visited all activity points. Activity point 1 was called "Agile duck-bill", where the pupils tried out and learned about various preconditions for certain types of physical activity. The key competences involved communication, personal, social, and learning. The second activity point was called "Forest supermarket" and focused on the issue of a sedentary lifestyle. The key competences involved communication, personal, social, learning, problem solving, professional, and civic. The following activity point called "Juicy blueberry" focused on determining the importance of fruit and vegetables in terms of a balanced diet. The key competences involved communication, personal, social, learning, professional, and civic. The fourth activity point was called "Oversalted chip", where the pupils were supposed to understand the negative health consequences of consuming fast food. The key competences involved personal, social, learning, and professional. The last activity point called "Great pyramid" invited the pupils to place various types of food into a pyramid. The key competences involved learning, problem solving, communication, professional, social and personal, professional, civic. During a break the pupils completed worksheets, and in groups though about the principal

\footnotetext{
1 "This article is the well-developed form which was presented in 1st International Conference on Lifelong Education and Leadership for ALL-ICLEL 2015 was occured in Czech Republic on 29-31 october 2015.”

${ }^{2}$ Ph.D., Palacký University in Olomouc, Faculty of Education, Department of Anthropology and Health Education,

${ }^{3}$ Ph.D., Palacký University in Olomouc, Faculty of Education, Department of Anthropology and Health Education, petr.zemanek@upol.cz
} jitka.tomanova@upol.cz
\end{abstract}


motivation question. The project was completed by a final assembly of all participants, and by joint reflection in classes.

The present paper is not a traditional field-based research study. This is a project day, which followed a previous questionnaire survey on pupils' healthy lifestyle and anthropometric measurement of pupils under the following project: The epidemic of obesity - a common problem: knowledge transfer, education, prevention under Reg. No. PL.3.22/2.3.00/11.02576.

Keywords: Project day; physical activity; diet; health; elementary school

\section{Introduction}

The issue of a healthy diet is as important as physical activity. In principle, both of these two components of a healthy lifestyle should be balanced. That means balanced energy intake and expenditure. Neither side of this imaginary equation can be changed without changing the other side (Stejskal, 2004; Pastucha, 2011). It is therefore not appropriate to artificially separate the two components of a healthy lifestyle. Combining health education with the school environment is obvious: it is because compulsory school attendance should be accompanied by basic principles of a healthy lifestyle. These trends are already enshrined in current educational programmes. The current curricular documents, which shape the contemporary education in the Czech Republic, implement the educational area of health education (Výživa, 2009; Bílá kniha - Národní program rozvoje vzdělávání v České republice. Ministerstvo školství, mládeže a tělovýchovy, 2001).

\section{Main project objective}

The main objective of the Project Day called "A sound mind in a sound body" was to, in a playful way, familiarize the pupils with basic information concerning diet and health benefits of physical activity.

\section{Preparation and organization of the project day}

In planning any project certain factors must be considered. The first is the time, i.e. development of a clear schedule of activities. What to do first, what to do next, how individual stages are linked. Another important factor is resources, especially human and material resources, we need to decide who to invite into the project, how many people will be involved. In terms of material resources we need to decide what materials and equipment the project requires. The third important area includes finance: what are the financial demands, will any material need to be purchased? How to save and how much we need to save? Time, resources and finance are important principles in the preparation of any project, including a school-based project (Svobodová et al., 2010; Coufalová, 2006). In the planning stage it is necessary to specify the outcome of the project, i.e. the final product. It is also important to develop a project schedule, i.e. what will take place when. This also determines the total length of the project. In terms of personnel it is necessary to determine the number of project participants, both students and teachers or other participants. It is also important to specify how the project will be organized and evaluated (Kratochvílová, 2006; Kindlmannová, 2013).

\section{Implementation of the project day}

The main part of the project day held on 2 December 2014 was attended by 69 pupils from an elementary school in Senice na Hané and was organized as group work in various thematic activity points; there were a total of five activity points, they are described in detail below. The pupils were given detailed information about the preparation and implementation of the project day. According to predetermined criteria the pupils were divided into groups. Each group visited all activity points. During the implementation of the project day it was necessary to ensure security of the participating pupils. In case of some activities there was a danger of injury (Mazáčová, 2007). The 
Tomanová, J., \& Zemánek, P. (2016). Project the day focused on physical activity and diet. International Journal of Human Sciences, 13(1), 1-6. doi:10.14687/ijhs.v13i1.3518

project was carried out in a school, the school management approved the project day, the pupils and their parents also gave an informed consent. The project day was performed in accordance with the ethical rules applicable to this type of research.

The project mentioned above had some limitations: it was subject to approval of the schools involved, time and capacity of the schools, consent of the pupils and their parents, time and physical possibilities of the authors and students involved in the project day.

Activity point 1: "Agile duck-bill"

Table 1. Basic characteristics of activity point 1 - overview

\begin{tabular}{|c|c|}
\hline OBJECTIVES & $\begin{array}{l}\text { The pupils try out their physical activity aptitude. } \\
\text { The pupils realize their aptitude for specific physical } \\
\text { activity. }\end{array}$ \\
\hline OUTCOME(S) & $\mathrm{X}$ \\
\hline TOPIC & $\begin{array}{l}\text { types of physical activity in terms of physical activity } \\
\text { aptitude }\end{array}$ \\
\hline KEY COMPETENCES & learning, communication, social and personal \\
\hline CROSS-CURRICULAR TOPICS & personality and social education \\
\hline ORGANIZATION OF ACTIVITY POINT & 1 teacher, $1-2$ students \\
\hline DURATION & $20 \mathrm{~min}$. \\
\hline MATERIALS AND EQUIPMENT & $\begin{array}{l}\text { slackline, scarf ( } 5 \text { pcs), crepe paper ribbons, small } \\
\text { balls ( } 5 \text { pcs), cardboard with a hole, cards with } \\
\text { pictures of various sports equipment }\end{array}$ \\
\hline
\end{tabular}

A joint discussion about sports that students do or would like to do was followed by various thematic points. The pupils tested their flexibility by crawling through cardboard with a hole. They also tried aiming at a target. On the floor there was a large coloured target made of crepe paper and circles, which the pupils tried to hit with balls. Another activity focused on fast reactions and was done in pairs. The players had identical numbers of cards with different sports pictures. These cards were gradually turned to reveal the pictures. If both players had the same picture they had to catch the ball located between them as quickly as possible. The game finished when the players ran out of cards in the pack. The winner was the player with more cards. Another joint activity tested the pupils' ability to work together. A pair of pupils held the four corners of a scarf. On the scarf they placed a plastic or sponge ball. Their task was to hit a basket with the ball, they were only allowed to touch the ball, they were not allowed to speak during the activity. The pupils tried out balance on a slackline. After completing all points a joint reflection session was held. The pupils had space to comment on the activities (Pastucha, 2011; Stejskal, 2004; Minaříková, 2014).

Activity point 2: "Forest supermarket"

Table 2. Basic characteristics of activity point 2 - overview

\begin{tabular}{|l|l|}
\hline OBJECTIVES & $\begin{array}{l}\text { In their own words the pupil explain the term } \\
\text { "sedentary lifestyle" }\end{array}$ \\
\hline TOPIC & sedentary lifestyle \\
\hline KEY COMPETENCES & $\begin{array}{l}\text { learning, problem solving, communication, social } \\
\text { and personal, professional, civic }\end{array}$ \\
\hline CROSS-CURRICULAR TOPICS & $\begin{array}{l}\text { personality and social education, environmental } \\
\text { education }\end{array}$ \\
\hline
\end{tabular}


Tomanová, J., \& Zemánek, P. (2016). Project the day focused on physical activity and diet. International Journal of Human Sciences, 13(1), 1-6. doi:10.14687/ijhs.v13i1.3518

\begin{tabular}{|l|l|}
\hline ORGANIZATION OF ACTIVITY POINT & 1 teacher, 2 students \\
\hline DURATION & 20 min. \\
\hline MATERIALS AND EQUIPMENT & $\begin{array}{l}\text { colour cards symbolizing forest fruit (raspberries, } \\
\text { blackberries, blueberries, strawberries, nightshade, } \\
\text { amanita), card legends }\end{array}$ \\
\hline
\end{tabular}

The activity started after a brief discussion, which involved a demonstration of pictures of a "sitting" contemporary man and "moving" prehistoric man. The pupils were divided into three mixed groups and were supposed to collect as many fruits as they could during a specific time. The task was to collect as many edible fruits as possible. If any of the group members collected inedible fruit, it had to be returned into the forest with one edible berry. The winner was the team with the largest number of collected edible fruits (Hravě žij zdravě, 2013; Minaříková, 2014).

Activity point 3: "Juicy blueberry"

Table 3. Basic characteristics of activity point 3 - overview

\begin{tabular}{|l|l|}
\hline OBJECTIVES & $\begin{array}{l}\text { The pupils explain the importance of fruit and } \\
\text { vegetables for diet. The pupils specify an } \\
\text { appropriate daily dose of fruit and vegetables. }\end{array}$ \\
\hline TOPIC & $\begin{array}{l}\text { importance of fruit and vegetables in terms of a } \\
\text { balanced diet }\end{array}$ \\
\hline KEY COMPETENCES & $\begin{array}{l}\text { learning, communication, social and personal, } \\
\text { professional, civic }\end{array}$ \\
\hline CROSS-CURRICULAR TOPICS & $\begin{array}{l}\text { personality and social education, environmental } \\
\text { education }\end{array}$ \\
\hline ORGANIZATION OF ACTIVITY POINT & 1 teacher, 1 student \\
\hline DURATION & 10 min. \\
\hline MATERIALS AND EQUIPMENT & dummy fruit and vegetables, kitchen scales \\
\hline
\end{tabular}

From a theoretical perspective it was important to outline the importance of fruit and vegetables for our diet. Motivation questions were as follows: "Do you know how much fruit and vegetables we need to consume per day? Make a guess! Who is the closest? And do you know why we should eat fruit and vegetables?" The pupils were shown the amount of fruit and vegetables to be consumed during a single day. The amount of fruit and vegetables was put on the scales for the pupils to see. In this activity point the pupils selected the names of fruit and vegetables according to the colour of clothing. If for example a pupil had a red T-shirt on, he/she said tomato or strawberry, etc. (Brázdová, Matějová, 1996; Maňák, Švec, 2003; Minař́íková, 2014).

Activity point 4: "Oversalted chip"

Table 4. Basic characteristics of activity point 4 - overview

\begin{tabular}{|l|l|}
\hline OBJECTIVES & $\begin{array}{l}\text { The pupils understand the negative health } \\
\text { consequences of consuming fast food. }\end{array}$ \\
\hline TOPIC & "Fast food" meals \\
\hline KEY COMPETENCES & learning, social and personal, professional \\
\hline CROSS-CURRICULAR TOPICS & personality and social education \\
\hline ORGANIZATION OF ACTIVITY POINT & 1 teacher, 1 student \\
\hline DURATION & 20 min. \\
\hline MATERIALS AND EQUIPMENT & coloured balls, rope \\
\hline
\end{tabular}


This activity point focused on the current topic of eating in fast food stands and restaurants. The task was to "throw away" all junk food out of a circle made of a rope on the floor. In the ring there were coloured balls that represented healthy and unhealthy food (e.g. yellow balls - chips, blue balls - mineral water, green balls - broccoli, red balls - sweetened beverages). The pupils were divided into two mixed groups. The task was to throw away all balls that represented unhealthy food and drinks. Everything healthy should stay in the circle (Maňák, Švec, 2003; Výživa ve výchově ke zdraví, 2013; Minař́íková, 2014).

Activity point 5: "Great pyramid"

Table 5 . Basic characteristics of activity point 5 - overview

\begin{tabular}{|l|l|}
\hline OBJECTIVES & $\begin{array}{l}\text { In their own words the pupils explain the } \\
\text { principle of the food pyramid. This activity } \\
\text { invited the pupils to place various types of food } \\
\text { into a pyramid. }\end{array}$ \\
\hline TOPIC & $\begin{array}{l}\text { food pyramid } \\
\text { professional, social and personal, professional, } \\
\text { civic }\end{array}$ \\
\hline KEY COMPETENCES & personality and social education \\
\hline CROSS-CURRICULAR TOPICS & teacher, 1 student \\
\hline ORGANIZATION OF ACTIVITY POINT & 20 min. \\
\hline MATERIALS AND EQUIPMENT & $\begin{array}{l}\text { rope, dummy foods, food pyramid picture, } \\
\text { "Egyptian pyramid" picture }\end{array}$ \\
\hline
\end{tabular}

This activity point focused on the theory of the food pyramid. The pupils were explained the principle of the pyramid in simple terms. First the pupils looked at a picture of a pyramid and were supposed to figure out what it is and what it could be used for. They named various types of food they had seen on the picture. Another task was to place the dummy foods into a prepared "rope pyramid". A large pyramid was made on the floor. The pupils faced the pyramid and a picture of a certain type of food was placed behind them. On command, everybody turned around, took the picture and placed it correctly into the prepared "rope" pyramid (Výživa ve výchově ke zdraví, 2013; Minař́ková, 2014).

\section{Conclusion}

At the end of the project day the pupils and the teachers completed evaluation questionnaires. The evaluation questionnaires for pupils reflected their satisfaction with the organization of the project day. Their task was to describe the contribution of the project in terms of new knowledge. The questionnaires covered the evaluation of individual activities, their popularity and difficulty. The main objective of this project day was the application of knowledge about a healthy lifestyle in the development of a specific didactic tool. The project day included five activity points that correspond with the educational field of Man and Health characterized by the Framework educational programme for elementary education.

\section{References}

Bílá kniha - Národni program rozuoje vždèláváni v Ceské republice. Ministerstvo školství, mládě̌ze a tèlovýchovy. (2001). Retrieved from http://aplikace.msmt.cz/pdf/bilakniha.pdf.

Brázdová, Z., \& Matějová, H. (1996). Potravinová pyramida: manuál pro učitele. Brno: Vladimír Smrčka. Coufalová, J. (2006). Projektové vyučování pro proni stupeñ základni školy: náměty pro učitele. Praha: Fortuna. 
Hravě žij zdravě. (2013). Retrieved from http://www.soutez.hravezijzdrave.cz/.

Kindlmannová, J. (2013). Kličový rok: záăzitková pedagogika a projektová výuka pro základni školy v rámci projektu Prázdninové školy Lipnice. Praha: Prázdninová škola Lipnice.

Kratochvílová, J. (2006). Teorie a praxe projektové výnky. Brno: Masarykova univerzita.

Mańák, J., \& Švec, V. (2003). Výnkové metody. Brno: Paido.

Mazáčová, N. (2007). Možnosti a meze projektové výnky v soucáasné škole. Retrieved from http://clanky.rvp.cz/clanek/c/Z/1288/moznosti-a-meze-projektove-vyuky-v-soucasneskole.html/.

Minaříková, Z. (2014). Projektový den zamèrený na pohybovou aktivitu a żdravou vy̌żivu pro žáky na základní škole. Diplomová práce. PdF UP v Olomouci. Vedoucí práce: Jitka Tomanová

Pastucha, D. (2011). Pobyb v terapii a prevenci détské obezity. Praha: Grada.

Stejskal, P. (2004). Proč a jak se żdravě býbat. Břeclav: Presstempus.

Svobodová, R., Lacko, B., \& CingIL, O. (2010). Projektové rǐzeni a projektové vyučování, aneb, Jak na výnkové projekty podle zásad projektovébo ř́zení. Choceň: PM Consulting.

Výchova ke zdraví. (2009). Výživa - putováni za zdravím jídlem. Retrieved from http://www.vychovakezdravi.cz/clanky/vyziva/doporucene-metodiky.html.

Výżiva ve výchově ke zdravi: výnkový program pro pedagogy na 2. stupni ZŠ. (2013). Retrieved from http://www.msmt.cz/vzdelavani/zakladni-vzdelavani/vyziva-ve-vychove-ke-zdravivyukovy-program-pro-pedagogy. 